\title{
GEOLOGICAL CONTROLS ON RADON POTENTIAL IN SCOTLAND
}

\author{
Scheib, $C^{1}$, Appleton J. D. ${ }^{1}$, Miles J. C. H. ${ }^{2}$, Green, B. M. R. ${ }^{2}$, Barlow, T. S. ${ }^{1}$, and D. G. Jones ${ }^{1}$. \\ ${ }^{1}$ British Geological Survey, Keyworth, Nottingham NG12 5GG, UK. \\ ${ }^{2}$ Health Protection Agency-Radiation Protection Division, Chilton, Didcot, Oxon OX11 ORQ, \\ UK.
}

Corresponding author: Cathy Scheib, Email: cemery@bgs.ac.uk

\section{Synopsis}

${ }^{222} \mathrm{Rn}$, a natural radioactive gas produced by the radioactive decay of ${ }^{238} \mathrm{U}$, accounts for about $50 \%$ of the total radiation dose to the average person in the UK. Geology is the most important factor controlling the source and distribution of radon; which has been linked to an increased risk of lung cancer. In order to prevent the public receiving high exposures to radon, it is necessary to identify those areas most at risk. We present results of new mapping of radon potential for Scotland using a method that allows the spatial variation in radon potential to be delineated both within and between geological groupings.

The main geological and geochemical associations with moderate to high radon potential areas are described. The highest radon potential values in Scotland are associated with U-rich, highly evolved Siluro-Devonian biotite granite intrusions, notably those clustered within a zone to the west of Aberdeen and at Helmsdale, in Caithness. $U$ mineralisation plays a role in areas including the Helmsdale granite and the Middle Old Red Sandstone of the Orcadian Basin. Elevated radon potential is also associated with limestones - where fracture permeability is influential - and with Ordovician-Silurian greywackes. The radon potential of unconsolidated deposits, and how this affects the radon potential of the underlying bedrock, reflects both their permeabilities and their compositions. 


\section{Introduction}

Radon $\left({ }^{222} \mathrm{Rn}\right)$ is a natural radioactive gas produced by the radioactive decay of radium $\left({ }^{226} \mathrm{Ra}\right)$, which in turn is derived from the radioactive decay of uranium-238 $\left({ }^{238} \mathrm{U}\right)$. Uranium is found in small quantities in all soils and rocks, although the amount varies from place to place.

Radon provides about $50 \%$ of the total radiation dose to the average person in the UK (Watson et al., 2005). Radon decays to form radioactive particles that can enter the body by inhalation. Inhalation of the short-lived decay products of radon has been linked to an increase in the risk of developing lung cancer. A study pooling the results of 13 European case-control epidemiological studies of people exposed to radon at home (Darby et al., 2005) has confirmed the risk associated with the gas and indicates that it is responsible for about $2 \%$ of all deaths from cancer in Europe. In the UK it is estimated that 1100 deaths a year from lung cancer are related to indoor radon and these equate to $3.3 \%$ of all deaths from lung cancer. The risk from radon is around 25 times higher for cigarette smokers than for non-smokers. An estimated $24.7 \%$ of adults in Scotland smoked in 2007 (Scottish Household Survey, 2008) and it is estimated that at least $20-25 \%$ of all deaths in Scotland are smoking related. Scotland has the highest rates of lung cancer in Europe for both men and women, with most cases caused by smoking. Breathing radon in the indoor air of homes is the second largest cause of lung cancer deaths after smoking (NRPB, 2000). In order to prevent members of the public receiving high exposures to radon, it is necessary to identify those areas most at risk from high levels. This allows surveys of radon in existing houses to be directed to those areas where high radon levels are most likely to be found, and also facilitates the use of building regulations to help prevent high radon levels in new buildings (BRE, 1999). In this paper the results of new radon potential mapping for Scotland are presented, including an evaluation of the main geological and geochemical associations in moderate to high radon potential areas. This radon potential mapping method was originally developed for England and Wales (Miles and Appleton, 2005; Appleton and Miles, 2005; Miles et al., 2007) and allows the spatial variation in radon potential to be delineated, taking into account variations both within and between geological groupings. 


\subsection{Factors controlling radon concentration and distribution.}

Geology is the most important factor controlling the source and distribution of radon (Appleton and Miles, 2005) (Figures 1 and 2). Relatively high levels of radon emissions are associated with particular types of bedrock and unconsolidated deposits; for example, some (but not all) granites, limestones, phosphatic rocks, and shales rich in organic materials. In Scotland $21 \%$ of the total variation of indoor radon concentration can be explained by the mapped bedrock and superficial geology, whilst in England and Wales, and in Northern Ireland, approximately $25 \%$ and $13 \%$ respectively of the total variation can be explained by mapped geology (Appleton and Miles, 2009).

The release of radon from rocks and soils is controlled largely by the types of minerals in which uranium and radium occur. In magmas, the large, highly charged $\mathrm{U}^{4+}$ ion becomes concentrated in late-stage differentiates, often in accessory minerals such as zircon and allanite. In sedimentary rocks, phosphates and organic complexes may be a more important source of $U$ than primary minerals.

Once radon gas is released from minerals, its migration to the surface is controlled by the transmission characteristics of the bedrock and soil; the nature of the carrier fluids, including carbon dioxide gas and groundwater; meteorological factors such as barometric pressure, wind, relative humidity and rainfall; as well as soil permeability, drainage and moisture content (Ball et al., 1991; Appleton and Ball, 1995; Appleton and Ball, 2001; Appleton, 2005).

Radon released from rocks and soils is quickly diluted in the atmosphere so that concentrations in the open air are normally very low. However, radon that enters buildings, caves, mines, and tunnels can reach high concentrations in some circumstances. The construction methods and the degree of ventilation are important influences on radon levels in buildings. Soil gas radon enters buildings through cracks and openings in the foundations, aided by the pressure differential between the soil and the building. Almost all buildings exert a negative pressure (suction) on the soil because of the natural stack effect - hot air rising and drawing replacement air from under the building - a process that will be more efficient on higher permeability ground. Indoor radon levels fluctuate with outdoor temperature, 
and hence season. A person's exposure to radon will also vary according to how particular buildings and spaces are used.

\subsection{Radon Affected Areas}

Based on the estimated risks of lung cancer from prolonged exposure, an Action Level (AL) for radon in homes of $200 \mathrm{~Bq} \mathrm{~m}^{-3}$ has been established in the UK (NRPB, 1990). The Health Protection Agency (HPA) has recommended that parts of the UK with $1 \%$ probability or more of homes being above the Action Level should be designated as Radon Affected Areas.

The AL refers to the annual average concentration in a home, so radon measurements made by the HPA are carried out with two detectors (one each in a bedroom and a living room) over three months, to average out short-term fluctuations. These results are then corrected to an estimated annual average concentration, based on the outdoor temperature during the period of measurement (Miles, 2001).

In the early 1980s a national survey of radon in houses in the whole of the UK was carried out. The results showed that radon levels in Scotland were, on average, similar to those in the rest of the UK. The percentage of homes above the UK radon $A L$ varied considerably from one area of Scotland to another, as it does in the rest of the UK (NRPB, 2003). Radon Affected Area maps for Scotland were published in 1991 and 1993 (NRPB, 1991; NRPB, 1993). Since then, measurements have continued and the HPA has been working with the Scottish Government to identify areas of Scotland with elevated indoor radon levels and individual dwellings that are affected. Most recently, Radon Affected Area maps for Scotland were published in 2009 using a grid-square mapping approach (Green et al., 2009).

\section{Methodology}

\subsection{Radon mapping}

The cost-effective identification of (a) existing buildings with high radon levels and (b) those areas where protective measures need to be installed in new buildings, depends on the existence of accurate radon potential maps. The principal objective of radon potential mapping in the UK is to delineate the variation in probability that 
new or existing buildings will exceed the UK AL of $200 \mathrm{~Bq} \mathrm{~m}^{-3}$. The HPA and the British Geological Survey (BGS) have collaborated on the production of new radon potential information for Scotland, based on mapping the variation of radon both within and between geological units (Miles and Appleton, 2005).

For this integrated method, the land area is first divided up using a combination of geological characteristics derived from the BGS 1:50,000 scale digital bedrock and superficial geological map data, or 1:250,000 and 1:625,000 scale data for the relatively small areas where $1: 50,000$ scale data are not currently available. A simplified bedrock geology classification, broadly equivalent to that used for the BGS $1: 625,000$ scale map data was used to ensure continuity of bedrock geological units across 1: 50000 map sheet boundaries, to group geological units with similar characteristics, and to ensure that adequate numbers of indoor radon measurements were available for intra-geological unit grid square mapping. There are approximately 4800 named 1:50 000 scale bedrock units in Scotland which have been reduced to a simplified bedrock classification comprising 138 units. In addition, the 189 1:50 000 scale superficial geology units were grouped according to a simplified 10 unit system based on permeability and genetic type (see Table 1 in Miles and Appleton, 2005). The main simplified superficial geology units are clay-silt (mainly impermeable alluvium), diamicton (mainly glacial till, which is generally, though not always, relatively impermeable), sand and gravel (mainly permeable glaciofluvial deposits but also raised terrace, raised marine, marine beach and river terrace deposits) and peat. A total of 446 bedrock-superficial geology combinations resulted from the simplified classification and were used for this mapping. The HPA has a database of over 19,000 houses in which long-term measurements of radon concentration have been made in Scotland, and whose locations are accurately known. Each of these measurements is allocated to the appropriate geological combination underlying it.

Taking each bedrock-superficial geological combination in turn, the spatial variation of radon potential is mapped, treating the combination as if it were continuous over the land area. Where there are 100 or more indoor radon measurements on a bedrock-superficial geological combination, log-normal modelling (Miles, 1998) is used to estimate the radon potential in each 1-km grid square within that 
combination using the nearest 30 house radon measurement results to that square on that combination, or on the basis of all of the results in that square if that was 30 or more.

In cases where there are too few house radon results attributed to a geological combination to allow the spatial variation to be mapped, the average radon potential for all the houses on the combination is estimated and applied to the whole combination in each $100 \mathrm{~km}$ grid square of the British National Grid. Some combinations have too few results to allow radon potential to be calculated directly, and in these cases the data for similar combinations are grouped together, or radon potential is assigned by analogy with similar combinations. All of the radon potential data for different geological combinations are then combined to produce a map of variation in radon potential over the whole land surface. The resultant radon potential map (Figure 2 ) shows variation in radon potential both within and between the pre-defined bedrock-superficial combinations. This type of radon potential map is the most effective and meaningful way of representing spatial variations in radon potential data (Miles and Appleton, 2005). Lateral variation in indoor radon potential within geological units is observed where lithological variations or gradients occur within mapped units, where uranium mineralisation occurs or where transported material was derived from uranium rich areas and is variably distributed. This intrageological unit variation, where this applies, is reflected in the estimated radon potential for $1 \mathrm{~km}$ - geological combination polygons and results in a range of radon potential values for a specific bedrock-superficial combination.

Based on the joint HPA-BGS radon potential mapping, approximately $11 \%$ of Scotland (by surface area) is estimated to have $>1 \%$ of dwellings with radon above the $\mathrm{AL}$ of $200 \mathrm{~Bq} \mathrm{~m}^{-3}$. This is lower than in England and Wales, where approximately $27 \%$ of the land area is mapped as Radon Affected.

\subsection{Stream sediment geochemistry}

Stream sediment samples were collected in Scotland between $1970-1985$ by BGS's Geochemical Baseline Survey of the Environment (G-BASE) project and its predecessors. Sample collection and analytical methods are described in BGS (1993) and Johnson et al., 2005. Each of the stream sediment measurements were allocated 
to the appropriate bedrock- superficial geological combination underlying it. Results were then grouped by geological combination and summary statistics produced. From the suite of elements determined, only some are considered for this study: most importantly $U$ as the source of radon (Figure 3); in addition potassium (K), lanthanum (La), yttrium (Y), zirconium $(\mathrm{Zr})$, rubidium $(\mathrm{Rb})$ and strontium $(\mathrm{Sr})$ are considered as they can be used to assess whether $U$ is likely to be non-labile in resistate minerals, and for the identification of evolved, highly fractionated granite plutons, which may be associated with a high radon potential.

\subsection{Radon in soil gas and in situ gamma spectrometry}

Few indoor radon results were available for the relatively narrow and restricted outcrops of Carboniferous limestone in Scotland, rocks known to have a high radon potential in England and Wales (Miles and Appleton, 2005; Appleton and Miles, 2005). Soil gas radon and in situ gamma spectrometry measurements were therefore obtained on Carboniferous limestones and adjacent strata in areas close to housing in central Scotland in July-August 2007 in order to inform the assessment of their radon potential. Soil gas radon measurements were made at a depth of $80 \mathrm{~cm}$ using a Pylon AB-5 portable radiation monitor. Gamma spectrometry was carried out using an Exploranium GR-320 with a $76 \times 76 \mathrm{~mm} \mathrm{Nal}(\mathrm{TI})$ detector. 10 minute counts were obtained at a height of $1 \mathrm{~m}$ by mounting the detector on a tripod. With the detector at a height of $1 \mathrm{~m}$ it can detect gamma rays from an area within a 10-metre radius to a depth of approximately $30 \mathrm{~cm}$ (Atomic Energy Commission, 1972). Equivalent

uranium (eU) value was determined from the ${ }^{214} \mathrm{Bi}$ gamma peak. 


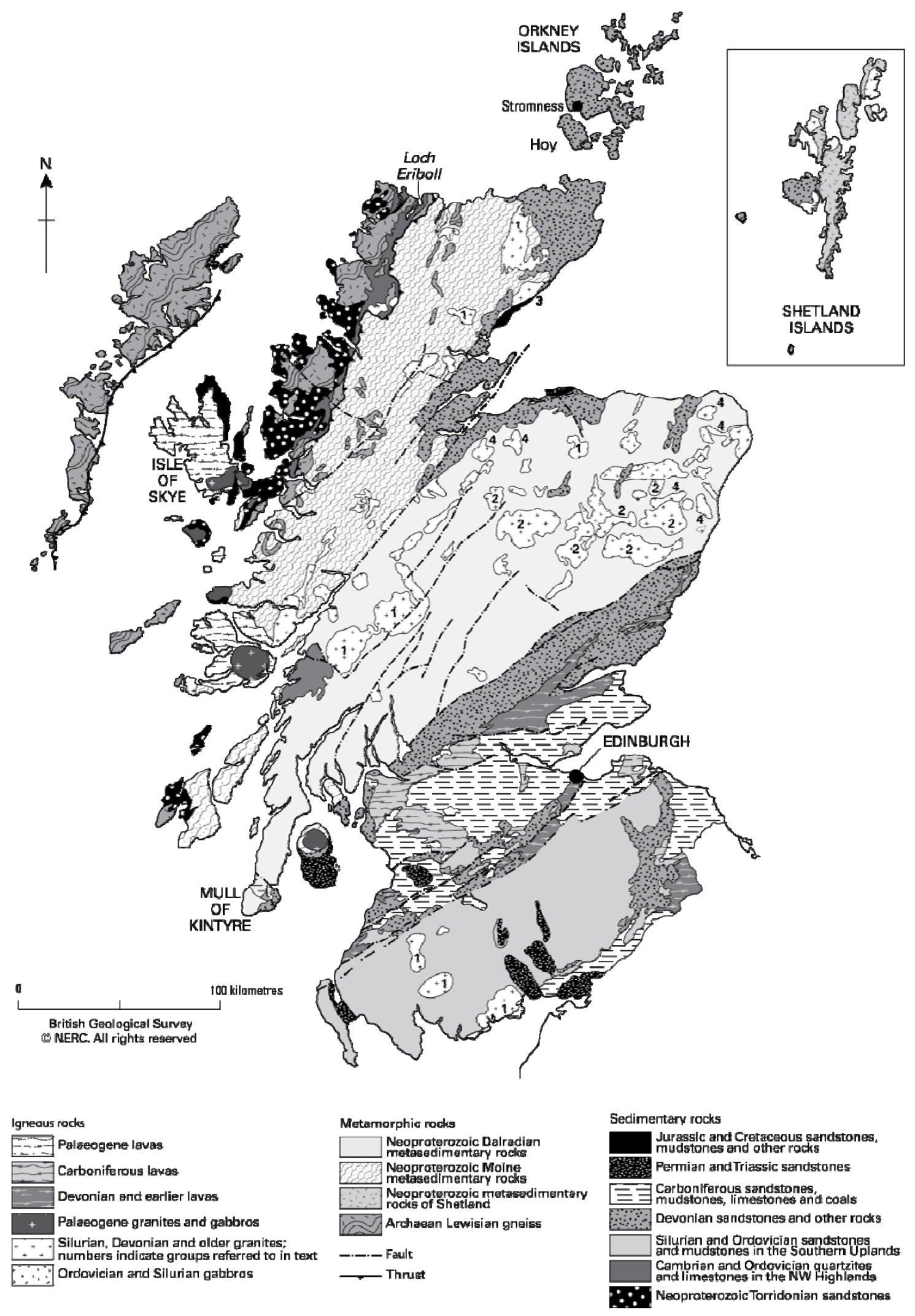

Figure 1. Generalised bedrock geological map of Scotland, derived from the BGS 1:625, 000 scale digital map data (BGS, 2007). Selected locations referred to in text are displayed. 


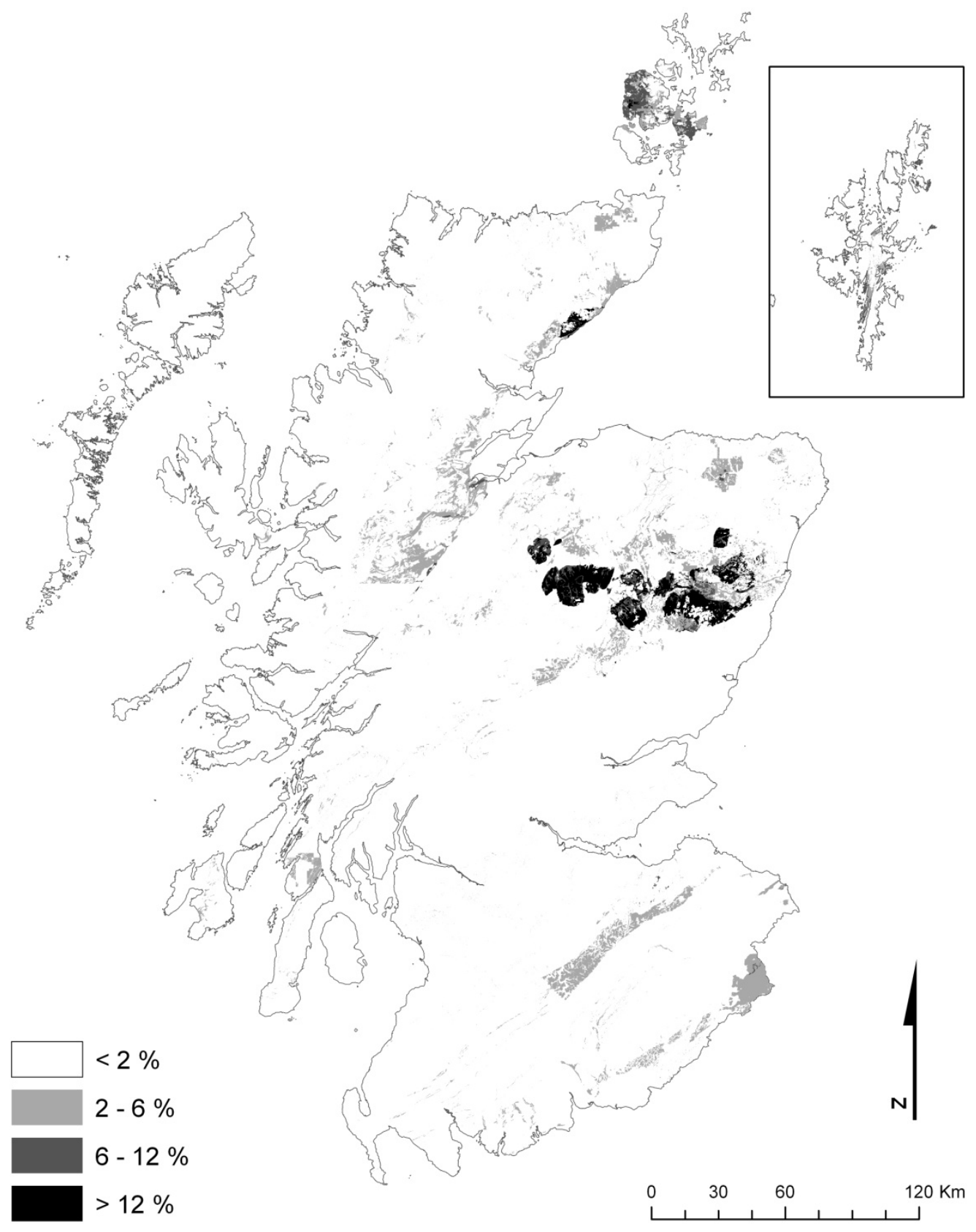

Figure 2. Provisional radon potential map of Scotland showing the percentage of dwellings estimated to exceed the radon Action Level of $200 \mathrm{~Bq} \mathrm{~m}^{-3}$ (\%>AL). 


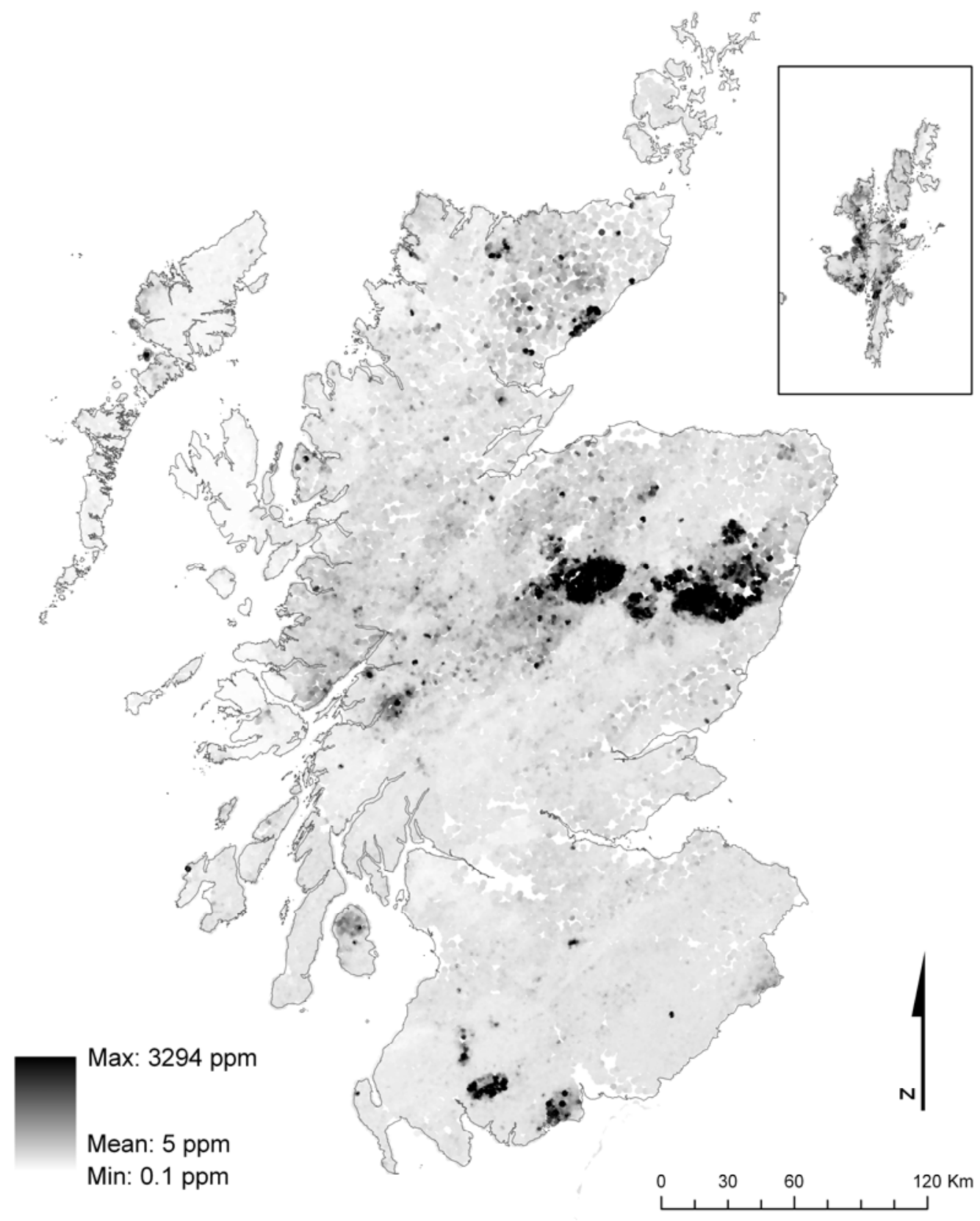

Figure 3. Uranium in stream sediments (ppm). Spatial variation interpolated by inverse distance weighting ( $250 \mathrm{~m}$ grid; maximum search radius of $1500 \mathrm{~m}$ ). 


\section{Radon potential and geology}

A small number of bedrock types lie beneath the radon prone areas of Scotland, shown in Figure 2. Following an initial overview of the geochemical associations with elevated radon, these bedrock units are described with an assessment of the factors controlling radon potential. We then consider the radon potential of superficial deposits.

\subsection{Geochemical associations related to radon potential in Scotland}

Selected stream sediment data, grouped by bedrock-superficial geology combination, were investigated in relation to radon potential. Although the geochemical data distributions on different parent material combinations varied, in general data were log-normally distributed and were therefore log transformed for statistical analysis. Indoor radon correlates most strongly with $\mathrm{U}$, followed by $\mathrm{Rb}, \mathrm{K}$, $\mathrm{Y}, \mathrm{La}$ and $\mathrm{Zr}$ in that order (Table 1). Multivariate factor analysis highlighted three dominant factors (Table 2): factor 1 accounts for $20.8 \%$ of the variance with indoor radon associated with $\mathrm{U}, \mathrm{Zr}$, $\mathrm{La}, \mathrm{Rb}$, and $\mathrm{K}$ as the dominant elements; factor $2(\mathrm{Y}, \mathrm{Rb}, \mathrm{K})$ accounts for $19.4 \%$ of the variance, and factor 3 ( $L a, U, R b, K$ ) accounts for $17.4 \%$ of the variance. The fact that these factor groups are very similar and together account for nearly $58 \%$ of the variance demonstrates the autocorrelation of these elements related to evolved granites and sediments of granitic origin. When the granitic bedrock data were removed, the remainder of the data displayed 3 factors of decreasing importance (Table 3): factor 1 accounts for $21.1 \%$ of the variance with $\mathrm{Rb}$ and $\mathrm{K}$ the dominant elements; factor 2 accounts for $18.9 \%$ of the variance $(U, \mathrm{Zr}$, $\mathrm{La}, \mathrm{Rb}, \mathrm{K}, \mathrm{Y}$ and indoor radon) and factor 3 accounts for $16.9 \%$ of the variance with $Y$ and La as the dominant elements. These factors again strongly indicate the influence of a granitic or acid metamorphic source component to sedimentary and metasedimentary assemblages and also the influence of granitic bedrock on superficial deposits. Both Table 2 and 3 indicate that indoor radon is most strongly related to $U$. 
Table 1. Correlation matrix of indoor radon $\left(\mathrm{Bq} \mathrm{m}^{-3}\right)$ and selected stream sediment data (ppm), all data log transformed. $N=>48,000$. Coefficients in bold; $p<0.0005$

\begin{tabular}{ccccccccc}
\hline & $\begin{array}{c}\text { Ln Indoor } \\
\text { Radon }\end{array}$ & Ln $U$ & Ln K & Ln La & LnY & Ln Zr & Ln Rb & Ln Sr \\
\hline $\begin{array}{c}\text { Ln Indoor } \\
\text { Radon }\end{array}$ & 1 & & & & & & & \\
Ln U & $\mathbf{0 . 3 9}$ & 1 & & & & & & \\
Ln K & $\mathbf{0 . 2 8}$ & $\mathbf{0 . 5 3}$ & 1 & & & & & \\
Ln La & $\mathbf{0 . 1 9}$ & $\mathbf{0 . 5 3}$ & $\mathbf{0 . 3 4}$ & 1 & & & & \\
Ln Y & $\mathbf{0 . 2 1}$ & $\mathbf{0 . 5 1}$ & $\mathbf{0 . 2 5}$ & $\mathbf{0 . 5 9}$ & 1 & & & \\
Ln Zr & $\mathbf{0 . 1 5}$ & $\mathbf{0 . 3 9}$ & $\mathbf{0 . 2 1}$ & $\mathbf{0 . 3 4}$ & $\mathbf{0 . 3 7}$ & 1 & & \\
Ln Rb & $\mathbf{0 . 3 3}$ & $\mathbf{0 . 6 3}$ & $\mathbf{0 . 8 9}$ & $\mathbf{0 . 4 3}$ & $\mathbf{0 . 3 7}$ & $\mathbf{0 . 1 8}$ & 1 & \\
Ln Sr & 0.00 & -0.02 & $-\mathbf{0 . 1 1}$ & 0.04 & 0.07 & 0.02 & -0.18 & 1 \\
\hline
\end{tabular}

Table 2. Loadings for forced 3-factor analysis of indoor radon and selected stream sediment data, all data log transformed, for the whole of Scotland.

\begin{tabular}{cccc} 
& Factor 1 & Factor 2 & Factor 3 \\
\hline Ln Indoor Radon & 0.39 & 0.16 & \\
Ln Zr & 0.45 & 0.24 & \\
Ln Y & 0.31 & 0.95 & \\
Ln U & 0.83 & 0.24 & 0.29 \\
Ln Sr & -0.28 & & \\
Ln Rb & 0.43 & 0.86 & 0.26 \\
Ln La & 0.44 & 0.13 & 0.49 \\
Ln K & 0.38 & 0.79 & 0.15 \\
\hline Proportion of & 20.8 & 19.4 & 17.4 \\
Variance (\%) & & & \\
\hline
\end{tabular}

Table 3. Loadings for forced 3-factor analysis of indoor radon and selected stream sediment data, all data log transformed, for all Scottish data excluding granitic bedrock.

\begin{tabular}{cccc}
\hline & Factor 1 & Factor 2 & Factor 3 \\
\hline Ln Indoor Radon & 0.18 & 0.31 & \\
Ln Zr & & 0.55 & 0.25 \\
Ln Y & & 0.32 & 0.93 \\
Ln U & 0.3 & 0.80 & 0.27 \\
Ln Sr & -0.26 & & 0.11 \\
Ln Rb & 0.90 & 0.34 & 0.27 \\
Ln La & 0.13 & 0.39 & 0.47 \\
Ln K & 0.82 & 0.33 & 0.18 \\
\hline Proportion of & 21.1 & 18.9 & 16.9 \\
Variance (\%) & & & \\
\hline
\end{tabular}




\subsection{Radon potential and bedrock geology}

\subsubsection{Granite intrusions}

Granite intrusions in Scotland display a range of radon potential values that relate to their age, composition and magma history. The highest radon potential values are associated with Siluro-Devonian (late Caledonian) granite intrusions, notably those clustered within a zone to the west of Aberdeen and at Helmsdale (Figure 2). These intrusions (e.g. Monadhliath, Cairngorm, Lochnagar, Glen Gairn, Ballater, Mt Battock, Cromar, Hill of Fare and Bennachie; referred to as 'Group 2', labelled 2 on Figure 1), and the Helmsdale intrusion in Caithness (labelled 3 on Figure 1), consist of geochemically highly evolved biotite granite $\left(\mathrm{SiO}_{2}\right.$ commonly $\left.\geq 73 \mathrm{wt} \%\right)$ in which the incompatible elements $U$ and Th have become unusually highly concentrated in a range of accessory minerals, including uraninite, monazite, zircon, allanite and apatite (Plant et al., 1980; Webb and Brown, 1984; BGS, 1991).

Of the Siluro-Devonian granitoids, higher $\mathrm{U}, \mathrm{K}, \mathrm{Rb}, \mathrm{Y}$ and La values occur in sediments derived from the highly fractionated biotite granites of the Grampian Region (Group 2, Table 4) rather than from the diorite complexes or the less evolved granodiorites and granites (e.g. Rannoch Moor, Etive, Rogart, Strath Halladale, Ben Rinnes, Loch Doon, Cairnsmore of Fleet and Criffel-Dalbeattie; Group 1, Table 4; labelled 1 on Figure 1). Stream sediment K/Rb ratios (266, Group 1; 140, Group 2) and $\mathrm{Rb} / \mathrm{Sr}$ ratios $(0.3$, Group $1 ; 2.1$, Group 2$)$ support the knowledge that the radon prone biotite granites of the Grampian Region are the more evolved of the two groups. The Helmsdale intrusion in Caithness also shows high $U$ values which are attributable to $U$ mineralisation, and displays one of the highest radon potentials in Scotland (Group 3, Table 4 \& Figure 4). Although stream sediment U levels are on average higher over the Group 2 highly fractionated biotite granites of the Grampian region, the radon potential is highest over the Helmsdale granite bedrock. Ordovician granodiorite to granite complexes (e.g. Moy, Strichen, Forrest of Deer, Aberdeen, Kemnay and Tillyfourie, Group 4, Table 4 \& Figure 4; labelled 4 on Figure 1) have an average radon potential of $2.2 \%>A L$. Stream sediments from catchments over these older intrusions indicate a lower $U$ median than the other granite groups. The Caledonian granites of Scotland and northern England are associated with lower radon potential than the younger Hercynian granites of south-west England, even 
though they have similar uranium concentrations. This reflects differences in the uranium-bearing minerals and especially in the solubility of the major uraniumbearing minerals in the two types of granites (Simpson et al., 1976; Ball and Basham, 1979; Ball et al., 1982; Basham et al., 1982). Uranium in the Caledonian granites is largely in the form of high-thorium uraninites and other chemically resistant minerals that are more resistant to weathering than the uraninites of south west England and consequently liberate less radon from the parent rock. In addition there are also considerable differences in the weathering histories of the two areas that affect the rate of release of radon. South-west England was not covered by ice sheets or active glaciers in the Pleistocene and consequently retained Tertiary erosion surfaces with deep weathering profiles containing radium-rich disaggregated granite. These weathering profiles are highly permeable and permit the free migration of radon gas. In contrast, the Caledonian granites in the Highlands of Scotland have been efficiently eroded by sheet and valley glaciers, resulting in the large scale removal of any earlier weathered and disaggregated granite zones. The absence of a thick permeable weathered profile reduces the migration of radon gas relative to the Hercynian granites of south-west England (Appleton and Ball, 1995). 
Figure 4. Box and whisker plots of radon potential (\%>AL) and log transformed stream sediment $U$ (ppm) for: Group 1, Siluro-Devonian plutons (Highlands and Southern Uplands); Group 2, Siluro-Devonian, evolved biotite granite plutons of the Grampian Region; Group 3, Helmsdale granite, Caithness and Group 4, Ordovician granodiorite-granite plutons (see Figure 1 for locations of examples of each group).

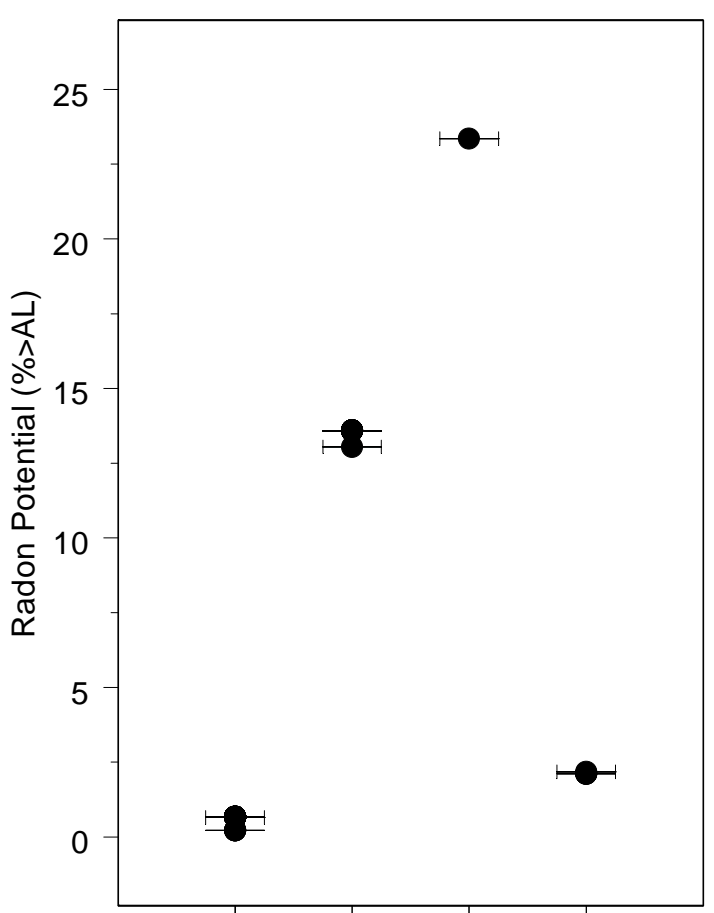

Group 1 Group 2 Group 3 Group 4

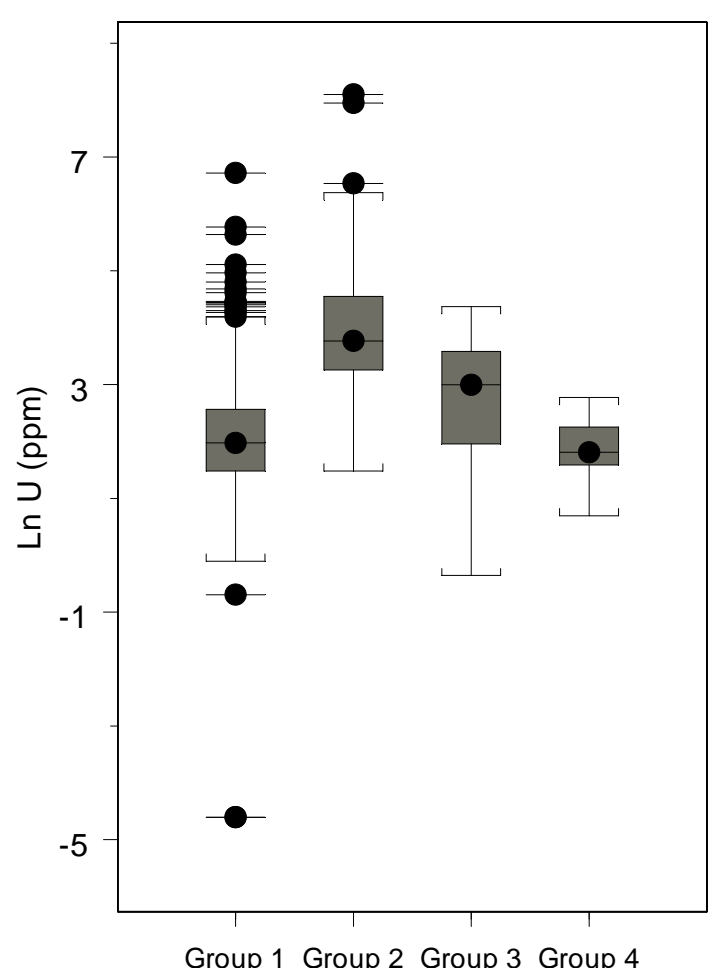

Group 1 Group 2 Group 3 Group 4 
Table 4: Summary statistics on bedrock for 4 granite groups, showing: average radon potential (Ave \% $>A L$ ), maximum radon potential $(\%>A L)$, geometric mean indoor radon ( $\mathrm{GM} \mathrm{Bq} \mathrm{m^{-3 }}$ ), maximum measured indoor radon ( $\mathrm{Max} \mathrm{Bq} \mathrm{m}^{-3}$ ), number of indoor radon measurements, selected stream sediment data (ppm) and number of stream sediment measurements.

\begin{tabular}{|c|c|c|c|c|c|c|c|c|c|c|c|c|}
\hline & \multicolumn{3}{|c|}{ Indoor Radon } & \multicolumn{9}{|c|}{ Stream Sediment Geochemistry (ppm) } \\
\hline & & & No: & & $\mathrm{Zr}$ & $\mathbf{Y}$ & $\mathbf{U}$ & $\mathrm{Sr}$ & $\mathbf{R b}$ & La & $\mathrm{K}(\%)$ & No: \\
\hline \multirow{4}{*}{$\begin{array}{c}\text { Group 1: } \\
\text { Siluro- } \\
\text { Devonian } \\
\text { plutons } \\
\text { (Highlands } \\
\text { and } \\
\text { Southern } \\
\text { Uplands) }\end{array}$} & $\begin{array}{c}\text { Ave } \\
\%>A L\end{array}$ & 0.6 & \multirow{4}{*}{87} & Mean & 533 & 38 & 15 & 286 & 94 & 61 & 2.5 & \multirow{4}{*}{563} \\
\hline & $\begin{array}{c}\operatorname{Max} \\
\%>A L\end{array}$ & 0.7 & & Median & 438 & 30 & 7 & 255 & 88 & 55 & 2.4 & \\
\hline & $\begin{array}{c}\mathrm{GM}^{-3} \\
\mathrm{~Bq} \mathrm{~m}^{-3}\end{array}$ & 27 & & Min & 111 & 9 & $<1$ & 51 & 33 & 19 & 0.9 & \\
\hline & $\begin{array}{c}\operatorname{Max} \\
\mathrm{Bq} \mathrm{m}^{-3}\end{array}$ & 312 & & Max & 2203 & 290 & 827 & 2162 & 294 & 386 & 5.6 & \\
\hline \multirow{4}{*}{$\begin{array}{c}\text { Group 2: } \\
\text { evolved } \\
\text { biotite } \\
\text { granite } \\
\text { plutons, } \\
\text { Grampian } \\
\text { Region }\end{array}$} & $\begin{array}{c}\text { Ave } \\
\%>A L\end{array}$ & 13.1 & \multirow{4}{*}{51} & Mean & 623 & 129 & 93 & 112 & 240 & 117 & 3.4 & \multirow{4}{*}{264} \\
\hline & $\begin{array}{c}\operatorname{Max} \\
\%>A L\end{array}$ & 13.6 & & Median & 483 & 80 & 43 & 97 & 249 & 99 & 3.3 & \\
\hline & $\begin{array}{c}\mathrm{GM}^{-3} \\
\mathrm{~Bq} \mathrm{~m}^{-3}\end{array}$ & 67 & & Min & 129 & 24 & 4 & 25 & 71 & 22 & 1.3 & \\
\hline & $\begin{array}{c}\operatorname{Max}_{\mathrm{Bq} \mathrm{m}^{-3}}\end{array}$ & 996 & & Max & 2485 & 568 & 3294 & 395 & 433 & 402 & 6.2 & \\
\hline \multirow{4}{*}{$\begin{array}{l}\text { Group 3: } \\
\text { Helmsdale } \\
\text { granite }\end{array}$} & $\begin{array}{c}\text { Ave } \\
\%>A L\end{array}$ & 23.4 & \multirow{4}{*}{5} & Mean & 518 & - & 24 & - & - & - & - & \multirow{4}{*}{20} \\
\hline & $\begin{array}{c}\operatorname{Max} \\
\%>A L\end{array}$ & 23.4 & & Median & 370 & - & 20 & - & - & - & - & \\
\hline & $\begin{array}{c}\mathrm{GM}^{-3} \\
\mathrm{~Bq} \mathrm{~m}^{-3}\end{array}$ & 121 & & Min & 346 & - & $<1$ & - & - & - & - & \\
\hline & $\begin{array}{c}\operatorname{Max} \\
\mathrm{Bq} \mathrm{m}^{-3}\end{array}$ & 399 & & Max & 1064 & - & 79 & - & - & - & - & \\
\hline \multirow{4}{*}{$\begin{array}{l}\text { Group 4: } \\
\text { Ordovician } \\
\text { granodiorite } \\
\text { to granite }\end{array}$} & $\begin{array}{c}\text { Ave } \\
\%>A L\end{array}$ & 2.2 & \multirow{4}{*}{27} & Mean & 610 & 64 & 7 & 225 & 110 & 89 & 2.7 & \multirow{4}{*}{31} \\
\hline & $\begin{array}{c}\operatorname{Max} \\
\%>A L\end{array}$ & 2.2 & & Median & 610 & 60 & 6 & 196 & 103 & 75 & 2.5 & \\
\hline & $\begin{array}{c}\mathrm{GM} \\
\mathrm{Bq} \mathrm{m}^{-3}\end{array}$ & 33 & & Min & 182 & 26 & 2 & 92 & 64 & 36 & 1.9 & \\
\hline & $\begin{array}{c}\operatorname{Max}_{\mathrm{Bq} \mathrm{m}^{-3}}\end{array}$ & 450 & & Max & 1521 & 142 & 16 & 903 & 221 & 315 & 4.9 & \\
\hline
\end{tabular}




\subsubsection{Limestone}

Uranium is mostly associated with finely divided organic matter and possibly also phosphatic material in the matrix of bio-clastic limestones. Although the overall concentration of $U$ in sediments from limestone catchments is low (medians range from 2.8 to $3.6 \mathrm{ppm}$, Table 5), high radon emissions can occur on limestone because of the high specific surface area and higher permeability of these uranium minerals (compared to dense, highly crystalline coherent minerals like zircon, for example) that permit efficient release of radon (Ball et al., 1991). In addition, high migration rates are promoted by the high joint and fracture permeability of the limestone and the permeability of overlying soils.

Metalimestone units form an important component of the Appin Group (part of the largely Neoproterozoic Dalradian Supergroup), which can be traced with remarkable continuity for some $300 \mathrm{~km}$ across the Scottish Highlands (Stone, 2008). The youngest part of the succeeding Argyll Group is also dominated by limestone. Dalradian metalimestones, of the combined Appin and Argyll Groups, outcropping on the Shetland Islands, display a moderate radon potential of $7.9 \%>A L$, with a stream sediment U median of 3.6 ppm (Table 5). Argyll Group metalimestone, outcropping sporadically from the Mull of Kintyre, and trending NE across Argyll to the Grampian Mountains, displays both a slightly lower radon potential and stream sediment $U$ median (Table 5).

The narrow, linear Cambro-Ordovician Durness Group stretches about $250 \mathrm{~km}$ from Loch Eriboll on the north coast of Scotland to southern Skye and comprises at least $750 \mathrm{~m}$ of mainly dolomitic limestones with an average radon potential of about 4 $\%>A L$ and relatively low stream sediment $\mathrm{U}$ (Table 5 ).

Most of the Carboniferous (Tournasian and Visean) limestones in England and Wales have high radon potential (generally $>10 \%$ >AL; Miles and Appleton, 2005; Appleton and Miles, 2005). In Scotland, Tournasian and Visean limestones in the Inverclyde and Strathclyde Groups crop out in thin bands across the Midland Valley and have an average radon potential of $1.4 \%>A L$, ranging up to $5.1 \%>A L$. Stream sediments overlying Namurian limestones of the Clackmannan Group are slightly more enriched in $U$ than those derived from the Tournasian and Visean limestones, perhaps 
reflecting the lower mobility of $U$ phases in anoxic, organic-rich environments (BGS, 1993). The Namurian limestones are characterised by higher average radon potentials of $6.8 \%>\mathrm{AL}$, ranging up to $9.8 \%>\mathrm{AL}$ (Table 5).

Although relatively few indoor radon results are available for the narrow outcrops of Carboniferous limestones in Scotland, they do occur in populated areas. Higher soil gas radon and $\mathrm{eU}$, on average, were recorded over the Carboniferous limestones than on adjacent strata (Table 6) at three sites to the $S$ and SE of Edinburgh and two to the SW of greater Glasgow, near Paisley. There is an overall positive correlation between soil gas radon and in situ gamma spectrometry eU (Figure 5). Additional indoor radon measurements carried out subsequent to the soil gas survey indicate a radon potential of about $10 \%>\mathrm{AL}$ on Carboniferous limestone in the Edinburgh area and $<1 \%>A L$ on the adjacent strata (shales, sandstones, and minor limestones) whereas in the Glasgow area the indoor radon data indicate a radon potential of about $6 \%>A L$ on Carboniferous limestones and again $<1 \%>A L$ on the adjacent shales, sandstones, and minor limestones. Although $\mathrm{eU}$ and soil gas radon were mostly lower on the adjacent strata than on the Carboniferous limestones, the differences in soil gas radon concentrations were relatively small (taking into account the highly variable nature of soil gas radon values), suggesting that a greater proportion of houses on limestones have elevated radon levels due to the higher fracture permeability of the limestone bedrock. 
Table 5. Summary statistics for selected bedrock units, showing: average radon potential (Ave \%>AL), maximum radon potential (Max \%>AL), geometric mean indoor radon ( $\mathrm{GM} \mathrm{Bq} \mathrm{^{-3 }}$ ), maximum recorded indoor radon ( $\mathrm{Max} \mathrm{Bq} \mathrm{m}^{-3}$ ), number of indoor radon measurements, $U$ stream sediment data $(\mathrm{ppm})$ and number of stream sediment $U$ measurements.

Indoor radon

$U$ in stream sediments

\begin{tabular}{|c|c|c|c|c|c|c|c|c|}
\hline Bedrock & Ave $\%>A L$ & $\underset{\%>A L}{\operatorname{Max}}$ & $\underset{\mathrm{Bq} \mathrm{m}^{-3}}{\mathrm{GM}}$ & $\underset{\mathrm{Bq} \mathrm{m}^{-3}}{\operatorname{Max}}$ & No: & \multicolumn{2}{|c|}{ U (ppm) } & No: \\
\hline $\begin{array}{l}\text { mudstone, } \\
\text { siltstone and } \\
\text { sandstone }\end{array}$ & 5.3 & 9.0 & 34 & 399 & 17 & & & \\
\hline $\begin{array}{l}\text { Namurian } \\
\text { limestone }\end{array}$ & 6.8 & 9.8 & 39 & 690 & 21 & $\begin{array}{l}\text { Median } \\
\text { Max }\end{array}$ & $\begin{array}{l}3.5 \\
5.6\end{array}$ & 20 \\
\hline $\begin{array}{c}\text { Tournasian- } \\
\text { Visean limestone }\end{array}$ & 1.4 & 5.1 & 24 & 2190 & 115 & $\begin{array}{l}\text { Median } \\
\text { Max }\end{array}$ & $\begin{array}{l}3.2 \\
3.7\end{array}$ & 5 \\
\hline $\begin{array}{l}\text { Devonian Middle } \\
\text { Old Red } \\
\text { Sandstone of the } \\
\text { Orcadian Basin }\end{array}$ & 1.9 & 11.9 & 27 & 5171 & 532 & $\begin{array}{l}\text { Median } \\
\text { Max }\end{array}$ & $\begin{array}{r}3.0 \\
47.5\end{array}$ & 307 \\
\hline $\begin{array}{l}\text { Devonian Lower } \\
\text { Old Red } \\
\text { Sandstone of the } \\
\text { Orcadian Basin }\end{array}$ & 5.3 & & 44 & 325 & 8 & $\begin{array}{l}\text { Median } \\
\text { Max }\end{array}$ & $\begin{array}{r}3.0 \\
12.0\end{array}$ & 41 \\
\hline $\begin{array}{l}\text { Devonian mafic } \\
\text { lava and tuff }\end{array}$ & 4.1 & & 52 & 577 & 34 & $\begin{array}{l}\text { Median } \\
\text { Max }\end{array}$ & $\begin{array}{c}5.9 \\
34.1\end{array}$ & 98 \\
\hline $\begin{array}{c}\text { Silurian } \\
\text { greywacke, } \\
\text { Riccarton Group }\end{array}$ & 3.9 & & 34 & 189 & 6 & $\begin{array}{l}\text { Median } \\
\text { Max }\end{array}$ & $\begin{array}{l}2.9 \\
7.9\end{array}$ & 7 \\
\hline $\begin{array}{c}\text { Silurian } \\
\text { greywacke, } \\
\text { Hawick Group }\end{array}$ & 0.2 & 0.6 & 31 & 294 & 168 & $\begin{array}{l}\text { Median } \\
\text { Max }\end{array}$ & $\begin{array}{c}3.2 \\
25.7\end{array}$ & 353 \\
\hline $\begin{array}{c}\text { Silurian } \\
\text { greywacke, Gala } \\
\text { Group }\end{array}$ & 0.5 & 0.99 & 28 & 341 & 136 & $\begin{array}{l}\text { Median } \\
\text { Max }\end{array}$ & $\begin{array}{c}3.4 \\
25.1\end{array}$ & 658 \\
\hline $\begin{array}{c}\text { Ordovician } \\
\text { greywacke, } \\
\text { Tappin to Scaur } \\
\text { Groups }\end{array}$ & 1.3 & 4.2 & 26 & 432 & 98 & $\begin{array}{l}\text { Median } \\
\text { Max }\end{array}$ & $\begin{array}{r}2.5 \\
11.8\end{array}$ & 747 \\
\hline $\begin{array}{l}\text { Cambro- } \\
\text { Ordovician } \\
\text { Durness Group } \\
\text { dolomitic } \\
\text { limestone }\end{array}$ & 4.1 & 4.2 & 44 & 407 & 17 & Median & 2.4 & 20 \\
\hline $\begin{array}{l}\text { Dalradian, Argyll } \\
\text { Group } \\
\text { metalimestone }\end{array}$ & 3.3 & & 46 & 388 & 14 & $\begin{array}{l}\text { Median } \\
\text { Max }\end{array}$ & $\begin{array}{c}2.8 \\
11.8\end{array}$ & 40 \\
\hline $\begin{array}{l}\text { Dalradian, Appin } \\
\text { and Argyll Groups } \\
\text { metalimestone, } \\
\text { Shetland Islands }\end{array}$ & 7.9 & & 49 & 288 & 11 & $\begin{array}{l}\text { Median } \\
\text { Max }\end{array}$ & $\begin{array}{l}3.6 \\
6.6\end{array}$ & 9 \\
\hline $\begin{array}{l}\text { Dalradian, Appin } \\
\text { and Argyll Groups } \\
\text { psammite, pelite } \\
\text { and semipelite, } \\
\text { Shetland Islands }\end{array}$ & 3.2 & 4.0 & 34 & 606 & 25 & $\begin{array}{l}\text { Median } \\
\text { Max }\end{array}$ & $\begin{array}{l}5.0 \\
62.2\end{array}$ & 71 \\
\hline
\end{tabular}


Table 6. Soil gas radon $\left(\mathrm{Bq} \mathrm{I}^{-1}\right)$ at $80 \mathrm{~cm}$ depth and in situ gamma spectrometry measurements for sites on Carboniferous limestone and adjacent strata in Central Scotland. Between 14-16 soil gas and in situ gamma spectrometry measurements were taken on each site.

\begin{tabular}{cccccc}
\hline & & \multicolumn{2}{c}{ Carboniferous limestone } & \multicolumn{2}{c}{ Adjacent strata } \\
\hline Area & Site & Radon $\mathrm{Bq} \mathrm{I}^{-1}$ & $\mathbf{e U}$ (ppm) & Radon Bq I $^{-1}$ & $\mathbf{e U ~ ( p p m ) ~}$ \\
\hline S. Edinburgh & Cousland & 87 & 1.5 & 62 & 1.6 \\
S. Edinburgh & Mayfield & 109 & 2.1 & 96 & 1.7 \\
S. Edinburgh & Ferniehill & 23 & 1.5 & 45 & 1.3 \\
SW. Glasgow & Roughmussel & 32 & 1.6 & 18 & 1.4 \\
SW. Glasgow & Dunterlie & 30 & 1.4 & 14 & 1.0 \\
SUMMARY & ALL & 58 & 1.6 & 39 & 1.4 \\
\hline
\end{tabular}

Figure 5. Average in situ gamma spectrometry eU (ppm) and soil gas radon at 80 $\mathrm{cm}$ depth $\left(\mathrm{Bq} \mathrm{I}^{-1}\right)$ for five sites on Carboniferous limestone and adjacent strata in Central Scotland.

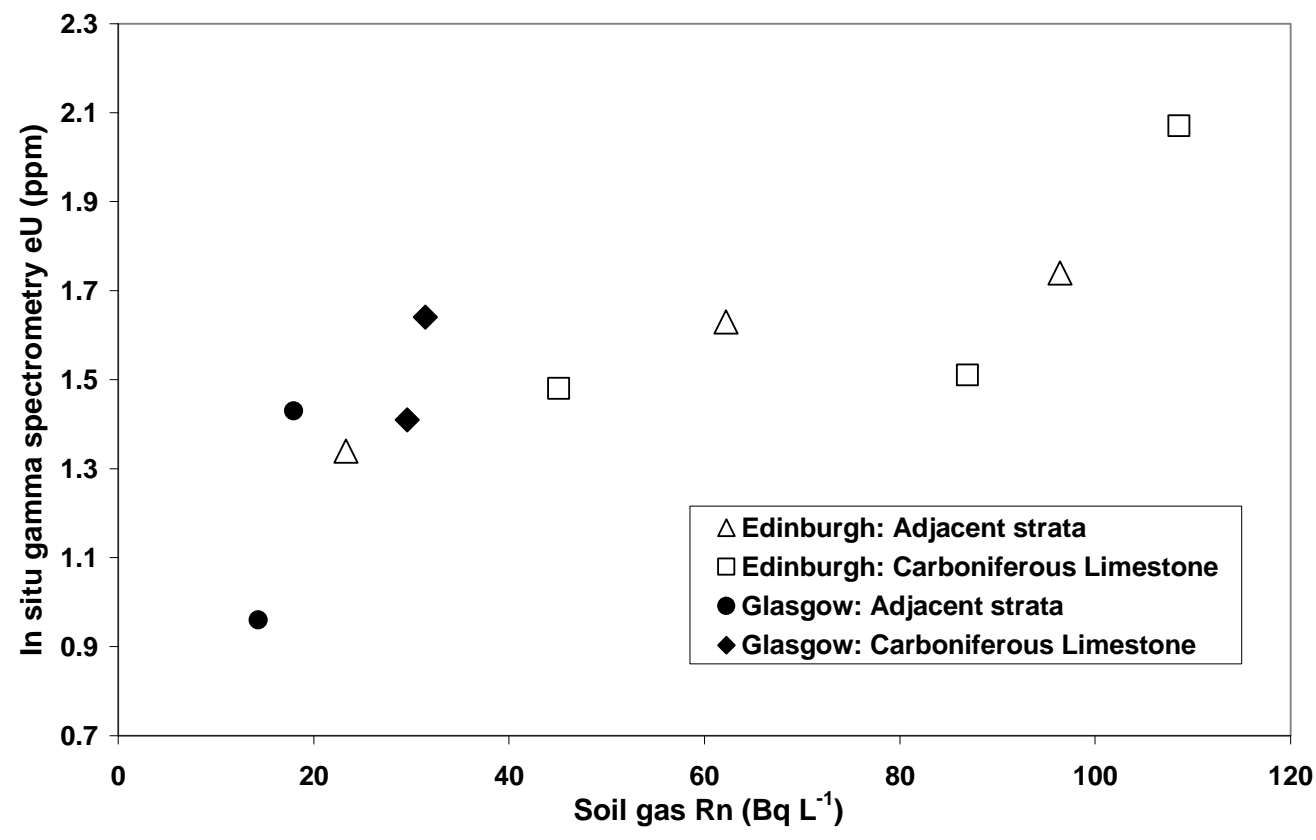




\subsubsection{Devonian strata: Old Red Sandstone lithofacies}

The Old Red Sandstone lithofacies, is an assemblage of fluvial, aeolian and lacustrine rocks that displays a range of radon potential values. The Lower Old Red Sandstone bedrock of the Orcadian Basin has a provisional radon potential of $5.3 \%>A L$, although additional indoor radon measurements are required as this is based on only 8 measurements. In contrast, the Middle Old Red Sandstone bedrock of the Orcadian Basin has an average radon potential of only $1.9 \%>\mathrm{AL}$ although this ranges up to $11.9 \%>A L$ (number of measurements $=532$ ). Whereas the recorded geometric mean (GM) for the Middle Old Red Sandstone bedrock of the Orcadian Basin was only 27 $\mathrm{Bq} \mathrm{m} \mathrm{m}^{-3}$, the maximum value was $5171 \mathrm{~Bq} \mathrm{~m}^{-3}$, the highest recorded indoor radon measurement made to date in Scotland. Median stream sediment $U$ for the Lower and Middle Old Red Sandstone are the same, although higher sediment U concentrations have been recorded for some samples from the Middle Old Red Sandstone (Table 5). These higher $U$ values, from the lacustrine facies, suggest an association of $U$ with the clay and colloidal fraction of sediments in the Orcadian Basin drainage system during deposition. Within this lacustrine sequence it is recognised that $\mathrm{U}$ occurs with the dark, organic rich and phosphatic horizons and that it has been remobilised during later faulting, producing further concentrations (Institute of Geological Sciences, 1978 \& 1979). Disseminated U mineralisation and locally enhanced $U$ concentrations are present in the Middle Old Red Sandstone in the Yesnaby and Stromness districts of West Mainland, Orkney (Michie, 1972), in a breccia zone east of Stromness at the Mill of Cairson (Institute of Geological Sciences, 1978), and in phosphatic siltstones and dark shales. In the Caithness area, uranium-lead-fluorspar mineralisation affects the Helmsdale granite and the Ousdale Arkose Formation. All of the above locations of known $U$ mineralisation show evidence of elevated radon: Yesnaby and west Stromness ( $>10 \%>A L)$; east of Stromness at the Mill of Cairson ( $>8 \%>A L)$; and the Helmsdale area (ranging up to $46.8 \%>A L)$.

Lower radon potential and stream sediment U characterise Old Red Sandstone Supergroup bedrock on the north east coast at Aberdeen ( $<0.1 \%>A L, G M 17 \mathrm{~Bq} \mathrm{~m}^{-3}$, median sediment U $2.1 \mathrm{ppm}$ ) and Upper Old Red Sandstone bedrock cropping out on 
Dunnet head and the Orkney Island of Hoy $\left(<0.1 \%>A L, G M 13.7 \mathrm{~Bq} \mathrm{~m}^{-3}\right.$, median sediment U $2.0 \mathrm{ppm})$.

\subsubsection{Ordovician-Silurian Greywacke of the Southern Upland Terrane}

Ordovician greywackes have a radon potential on bedrock that ranges up to 4.2 $\%>A L$ (Table 5) although it decreases progressively from the NE to SW, suggesting a lateral variation in composition. The succeeding Gala and Hawick Group greywackes display low radon potential whilst the Riccarton Group greywacke - that is significantly richer in $\mathrm{Rb}$ and has a much higher $\mathrm{Rb} / \mathrm{Sr}$ ratio than the Gala or Hawick Group units (Stone et al., 2004) implying an evolved granitic sediment source displays a provisional moderate radon potential of $3.9 \%>A L$ (Table 5), although more measurements would be required to confirm this.

\subsubsection{Other bedrock types with elevated radon potential}

Other radon prone bedrock units that do not fit the above generic headings include:

(i) Late Jurassic mudstones, siltstones and sandstones along the north east coast near Helmsdale (Table 5). Although it is possible that these strata are locally influenced by high $U$ from the adjacent $U$-mineralised Helmsdale granite. Along the coast to the SW at Brora- away from the Helmsdale granite, the Jurassic outcrop is not radon prone.

(ii) Psammites, pelites and semipelites of the combined Appin and Argyll Dalradian Groups, outcropping on the Shetland Islands, show both high maximum $U$ in stream sediments and elevated radon potential (up to $4 \%>A L$, Table 5).

(iii) Devonian mafic lavas and tuffs, on the border surrounding the Cheviot granite exhibit both elevated stream sediment $U$ (median $6 \mathrm{ppm}$ ) and radon potential (4.1 $\%>A L ;$ Table 5). $U$ mineralisation has been recorded to the south of the border in the Cheviot Hills (Haslam, 1975). 


\subsection{Radon potential and superficial geology}

The radon potential of unconsolidated deposits reflects either their permeability or composition, and in some cases, both. For example, impermeable clays tend to have low radon potential, mainly because low permeability restricts the flow of radonbearing air from the ground into buildings. In contrast, permeable sand and gravel and river terrace deposits commonly display higher radon potential relative to bedrock because high permeability and surface area facilitate both the release of radon and its flow from the ground into buildings. Composition also plays a role, for example, if fragments and mineral grains of uranium-rich granites are included in superficial material, they will lead to high radon in soils and dwellings, especially when the superficial deposits are highly permeable sands and gravels (Appleton, 2005). Variations in composition of the superficial deposits within the generic groupings will lead to a variation in the effects observed.

Increased radon potential of permeable glaciofluvial deposits relative to bedrock and more impermeable superficial deposits is observed on (i) the evolved biotite 'Group 2 ' granite plutons of the Grampian Region - where all superficial deposits exhibit a high radon potential, suggesting a local source or influence from the uranium-rich granite bedrock; (ii) the Hawick Group greywacke of the Southern Uplands; (iii) Appin Group pelite, graphite and calcareous pelite; and (iv) the Loch Eil Group psammite and the Glenfinnan Group psammite and pelite of the Moine Supergroup (Table 7). The reverse is true of the Middle Old Red Sandstone of the Orcadian Basin where glaciofluvial deposits have lower radon potential than bedrock, suggesting that these are derived from a lower $U$ source. Similarly, superficial deposits overlying Ordovician greywackes have lower radon potential than the bedrock, suggesting that these may be derived from a lower $U$ source or that the bedrock permeability may be greater than that of the superficial deposits.

Lower radon potential and GM indoor radon associated with glacial till and other clay-rich superficial deposits overlying Hawick Group greywacke bedrocks (Table 7) may reflect lower relative permeability.

Evidence of locally derived, $U$ rich material influencing radon potential is evident on the Grampian Group psammite and semipelite where all superficial deposit types have a higher radon potential than this bedrock; glaciofluvial deposits have an 
average radon potential of $0.8 \%>\mathrm{AL}$ (Table 7 ) but this ranges up to $5.4 \%>\mathrm{AL}$ in areas close to the U-rich evolved biotite granite plutons of the Grampian Region. Median stream sediment $U$ values derived from bedrock and glaciofluvial deposits are similar, suggesting that lateral variations in permeability may also influence radon potential. The influence from the uranium-rich Grampian granites is also apparent on the Argyll Group psammites, pelites and semipelites (Table 7) where higher radon potentials are found adjacent to the evolved biotite granite plutons. 
Table 7. Effects of superficial deposits on a range of bedrock types showing: average radon potential (\%>AL), maximum radon potential (\%>AL), Geometric Mean (GM) indoor radon $\left(\mathrm{Bq} \mathrm{m}^{-3}\right)$, maximum measured indoor radon $\left(\mathrm{Bq} \mathrm{m}^{-3}\right)$, number of indoor radon measurements, median $U$ in stream sediments (ppm) and number of $U$ stream sediment measurements.

\begin{tabular}{|c|c|c|c|c|c|c|c|c|c|}
\hline \multirow[b]{2}{*}{$\begin{array}{l}\text { Bedrock } \\
\text { Geology }\end{array}$} & \multirow[b]{2}{*}{$\begin{array}{l}\text { Superficial } \\
\text { deposit }\end{array}$} & \multicolumn{5}{|c|}{ Indoor Radon } & \multicolumn{3}{|c|}{ Stream Sediment } \\
\hline & & $\begin{array}{c}\text { Ave. } \\
\text { Radon } \\
\text { Potential } \\
(\%>A L) \\
\end{array}$ & $\begin{array}{c}\text { Max. } \\
\text { Radon } \\
\text { Potential } \\
(\%>A L) \\
\end{array}$ & $\begin{array}{l}\mathrm{GM} \\
\mathrm{Bq} \\
\mathrm{m}^{-3}\end{array}$ & $\begin{array}{c}\text { Max. } \\
\mathrm{Bq} \mathrm{m}^{-3}\end{array}$ & $\begin{array}{l}\text { No: } \\
\text { Rn }\end{array}$ & $\begin{array}{l}\text { Median U } \\
\text { (ppm) }\end{array}$ & $\begin{array}{l}\text { Max U } \\
\text { (ppm) }\end{array}$ & $\begin{array}{l}\text { No: } \\
\text { U }\end{array}$ \\
\hline \multirow{4}{*}{$\begin{array}{l}\text { Devonian } \\
\text { Middle Old Red } \\
\text { Sandstone of } \\
\text { the Orcadian } \\
\text { Basin }\end{array}$} & None & 2.0 & 11.9 & 27 & 5171 & 532 & 3.0 & 48 & 307 \\
\hline & Alluvium & 0.8 & 1.0 & 37 & 269 & 42 & 3.0 & 18 & 226 \\
\hline & Glacial Till & 1.3 & 13.4 & 26 & 1027 & 867 & 3.0 & 50 & 573 \\
\hline & Glaciofluvial & 0.5 & 2.4 & 26 & 318 & 251 & 3.0 & 30 & 121 \\
\hline \multirow{4}{*}{$\begin{array}{c}\text { Siluro- } \\
\text { Devonian } \\
\text { 'Group 2' } \\
\text { evolved biotite } \\
\text { granite plutons, } \\
\text { Grampian } \\
\text { Region } \\
\end{array}$} & None & 13.2 & 13.6 & 67 & 996 & 51 & 43.3 & 3294 & 272 \\
\hline & Alluvium & 13.2 & 25.8 & 75 & 554 & 122 & 24.0 & 320 & 143 \\
\hline & Glacial Till & 9.8 & 31.6 & 59 & 1180 & 149 & 26.5 & 492 & 408 \\
\hline & Glaciofluvial & 18.0 & 29.1 & 79 & 1776 & 200 & 25.4 & 110 & 49 \\
\hline \multirow{4}{*}{$\begin{array}{c}\text { Silurian Hawick } \\
\text { Group } \\
\text { greywacke }\end{array}$} & None & 0.2 & 0.6 & 31 & 294 & 168 & 3.0 & 26 & 353 \\
\hline & Alluvium & 0.5 & 1.9 & 35 & 321 & 131 & 2.8 & 23 & 310 \\
\hline & Glacial Till & 0.1 & 0.7 & 27 & 234 & 304 & 2.9 & 291 & 1304 \\
\hline & Glaciofluvial & 1.9 & 3.8 & 34 & 643 & 107 & 3.0 & 28 & 56 \\
\hline \multirow{4}{*}{$\begin{array}{c}\text { Ordovician } \\
\text { greywacke, } \\
\text { Tappin to } \\
\text { Scaur Groups }\end{array}$} & None & 1.3 & 4.2 & 26 & 432 & 98 & 2.5 & 12 & 747 \\
\hline & Alluvium & 0.9 & 3.0 & 33 & 155 & 48 & 2.4 & 8 & 232 \\
\hline & Glacial Till & 0.2 & 1.3 & 20 & 328 & 231 & 2.4 & 32 & 1341 \\
\hline & Glaciofluvial & 0.5 & 1.3 & 26 & 155 & 54 & 2.2 & 4 & 45 \\
\hline \multirow{4}{*}{$\begin{array}{l}\text { Dalradian } \\
\text { Southern } \\
\text { Highland } \\
\text { Group } \\
\text { psammite and } \\
\text { pelite } \\
\end{array}$} & None & 0.2 & 1.5 & 21 & 269 & 180 & 2.7 & 50 & 1295 \\
\hline & Alluvium & 0.9 & 2.0 & 24 & 213 & 95 & 2.9 & 19 & 256 \\
\hline & Glacial Till & 0.3 & 7.2 & 20 & 538 & 505 & 2.7 & 36 & 2044 \\
\hline & Glaciofluvial & 0.2 & 1.2 & 25 & 318 & 283 & 2.9 & 19 & 184 \\
\hline \multirow{4}{*}{$\begin{array}{l}\text { Dalradian } \\
\text { Argyll Group } \\
\text { psammite, } \\
\text { pelite and } \\
\text { semipelite }\end{array}$} & None & 3.2 & 4.0 & 27 & 399 & 223 & 3.0 & 46 & 978 \\
\hline & Alluvium & 2.6 & 18.7 & 38 & 689 & 243 & 4.8 & 90 & 260 \\
\hline & Glacial Till & 0.4 & 14.5 & 25 & 416 & 845 & 3.0 & 117 & 1428 \\
\hline & Glaciofluvial & 1.5 & 19.5 & 36 & 396 & 516 & 3.3 & 64 & 109 \\
\hline \multirow{4}{*}{$\begin{array}{c}\text { Dalradian } \\
\text { Appin Group } \\
\text { pelite, graphite } \\
\text { and calcareous } \\
\text { pelite }\end{array}$} & None & 0.1 & 0.1 & 23 & 141 & 23 & 3.2 & 136 & 307 \\
\hline & Alluvium & 0.5 & 0.5 & 31 & 180 & 21 & 3.3 & 9 & 68 \\
\hline & Glacial Till & 0.1 & 0.5 & 22 & 286 & 168 & 3.2 & 39 & 705 \\
\hline & Glaciofluvial & 2.6 & 3.0 & 31 & 522 & 68 & 3.1 & 28 & 82 \\
\hline \multirow{4}{*}{$\begin{array}{l}\text { Dalradian } \\
\text { Grampian } \\
\text { Group } \\
\text { psammite and } \\
\text { semipelite }\end{array}$} & None & 0.6 & 0.6 & 26 & 47 & 11 & 5.2 & 69 & 452 \\
\hline & Alluvium & 1.2 & 1.9 & 36 & 237 & 56 & 6.1 & 181 & 214 \\
\hline & Glacial Till & 0.3 & 2.6 & 23 & 582 & 183 & 4.9 & 310 & 1542 \\
\hline & Glaciofluvial & 0.8 & 5.4 & 31 & 412 & 195 & 4.6 & 69 & 265 \\
\hline \multirow{4}{*}{$\begin{array}{c}\text { Moine: Loch Eil } \\
\text { Group } \\
\text { psammite }\end{array}$} & None & 1.7 & 1.8 & 41 & 272 & 19 & 4.5 & 20 & 353 \\
\hline & Alluvium & $<0.1$ & $<0.1$ & 35 & 67 & 18 & 4.4 & 14 & 60 \\
\hline & Glacial Till & 1.3 & 2.2 & 29 & 202 & 57 & 4.4 & 46 & 527 \\
\hline & Glaciofluvial & 2.4 & 3.7 & 37 & 321 & 44 & 4.3 & 11 & 53 \\
\hline \multirow{4}{*}{$\begin{array}{c}\text { Moine: } \\
\text { Glenfinnan } \\
\text { Group, } \\
\text { psammites and } \\
\text { pelites }\end{array}$} & None & - & - & - & - & - & 4.6 & 14 & 180 \\
\hline & Alluvium & 1.7 & 1.7 & 70 & 157 & 6 & 4.0 & 11 & 34 \\
\hline & Glacial Till & 2.1 & 2.1 & 38 & 428 & 58 & 4.3 & 21 & 275 \\
\hline & Glaciofluvial & 7.5 & 8.6 & 32 & 261 & 16 & 4.9 & 8 & 22 \\
\hline
\end{tabular}




\section{Conclusions}

In Scotland $21 \%$ of the total variation of indoor radon concentration can be explained by the mapped bedrock and superficial geology. Based on the mapping presented here, approximately $11 \%$ of Scotland (by surface area) is estimated to have $>1 \%$ of dwellings with radon above the $\mathrm{AL}$ of $200 \mathrm{~Bq} \mathrm{~m}^{-3}$. This is lower than values in England and Wales, where approximately $27 \%$ of the land area is mapped as Radon Affected.

An evaluation of the main geological and geochemical associations with moderate to high radon potential areas revealed that:

(i) Indoor radon correlates most strongly with $\mathrm{U}$, followed by $\mathrm{Rb}, \mathrm{K}, \mathrm{Y}$, La and $\mathrm{Zr}$ in stream sediments. Factor analysis indicates the influence of granitic or acid metamorphic source components to the sedimentary and meta-sedimentary assemblages in Scotland and also the influence of U-enriched granitic bedrock on superficial deposits;

(ii) The highest radon potential values in Scotland are associated with SiluroDevonian (late Caledonian) granite intrusions, notably those clustered within a zone to the west of Aberdeen and at Helmsdale.

(iii) The elevated radon potential of limestones ranging in age from Dalradian to Carboniferous are thought to relate to the high specific surface area and permeability of the uranium minerals present that permit efficient release of radon and also to the high joint and fracture permeability of the limestone. Soil gas radon and in situ gamma spectrometry eU measured at 5 sites in populated areas are higher on Carboniferous limestones than on adjacent strata, supporting the contention that indoor radon measurements indicate that the units are radon prone.

(iv) The geometric mean indoor radon for the Middle Old Red Sandstone bedrock of the Orcadian Basin is only slightly above average but high recorded values indicate a variability that is probably related to U-mineralisation. Indeed, the locations of 
known U mineralisation, in the Caithness area and on the Orkney Islands, show evidence of elevated radon potential.

(v) Ordovician greywackes of the Southern Uplands Terrane have a moderate radon potential on bedrock that decreases progressively from the NE to SW, suggesting a lateral variation in composition. The Silurian Riccarton Group greywackes, that provide evidence of an evolved granitic sediment source also display a moderate provisional radon potential.

(vi) Other bedrock types that exhibit elevated radon potential include: Late Jurassic mudstones, siltstones and sandstones along the north east coast near Helmsdale, although it is likely that this is locally influenced by high $\mathrm{U}$ from the adjacent $\mathrm{U}$ mineralised Helmsdale granite; Devonian mafic lavas and tuffs, on the border surrounding the Cheviot granite; and Dalradian metasediments on the Shetland Islands.

(vii) The radon potential of unconsolidated deposits generally reflects their permeability and composition. Increased radon potential of permeable glaciofluvial deposits relative to bedrock and more impermeable superficial deposits is observed on, for example, the evolved biotite granite plutons of the Grampian Region and the Hawick Group greywackes of the Southern Uplands. Evidence of locally derived, Urich material influencing radon potential is evident on, for example, the Argyll Group psammites, pelites and semipelites where large ranges of radon potential are exhibited, with the highest values found adjacent to the U-rich evolved biotite granite plutons of the Grampian Region.

The reasons for elevated radon potential associated with specific bedrocks or superficial geological units are not always explained by geochemical and physical characteristics (such as permeability) and more indoor radon measurements over a range of units would help to better quantify these relationships, especially where the number of measurements currently available is relatively low. 


\section{Acknowledgements}

We acknowledge with thanks the funding and support of the Scottish Government for the indoor radon data, in particular Dr lan Hall, formerly Specialist Advisor Radioactive Waste, Environmental Quality Directorate, Scottish Government. Martin Gillespie and Neil Breward are thanked for suggesting improvements to early drafts of this paper which is published with the permission of the Director of the British Geological Survey (Natural Environment Research Council) and with the permission of the Health Protection Agency.

\section{References}

APPLETON, J.D., 2005. Radon in water and air. In Selinus, O. (ed.) Essentials of Medical Geology. Elsevier Academic Press. Amsterdam; London. pp. 227-262. APPLETON, J.D. and BALL, T.K., 1995. Radon and background radioactivity from natural sources: characteristics, extent and the relevance to planning and development in Great Britain. British Geological Survey, Technical Report WP/95/2. APPLETON, J.D. and BALL, T.K., 2001. Geological radon potential mapping. In Bobrowsky, P.T. (ed.) Geoenvironmental mapping: methods, theory and practice. Rotterdam: Balkema. pp.577-613.

APPLETON, J.D. and MILES, J.C.H., 2005. Radon in Wales. In: Nicol D and Bassett MG (Editors), Urban Geology of Wales, Volume 2. National Museum of Wales Geological Series. Cardiff.

APPLETON, J.D., MILES, J.C.H., 2009. A statistical evaluation of the geogenic controls on indoor radon concentrations and radon risk. Journal of Environmental Radioactivity (In Press doi:10.1016/j.jenrad.2009.06.002). 
ATOMIC ENERGY COMMISION. United States Of America, 1972. In situ Ge(Li) and $\mathrm{Nal}(\mathrm{TI})$ gamma-ray spectrometry. Health and safety laboratory publication, New York. Report number: HASL-258.

BALL, T.K. and BASHAM, I.R., 1979. Radioactive accessory minerals in granites from south west England. Proc. Ussher Soc., 4, 437-438.

BALL, T.K., BASHAM, I.R. and MICHIE, U.McL., 1982. Uraniferous vein occurrences of south-west England - paragenesis and genesis. In: Vein-type and Similar Uranium Deposits in Rocks Younger than Proterozoic, Vienna: International Atomic Energy Agency. pp. 113-156.

BALL, T.K., CAMERON, D.G., COLMAN, T.B. and ROBERTS, P.D., 1991. Behaviour of Radon in the Geological Environment - a Review. Quarterly Journal of Engineering Geology. 24, 169-182.

BASHAM, I.R., BALL, T.K., BEDDOE-STEPHENS, B. and MICHIE, U.McL., 1982. Uranium-bearing accessory minerals and granite fertility: 1 . Methods of identification and evaluation; II. Studies of granites from the British Isles. In: Proceedings of Symposium on Uranium Exploration Methods - Review of the NEA/IAEA R and D Programme, Paris, 1-4 June.

BGS (BRITISH GEOLOGICAL SURVEY), 1991. East Grampians. Regional Geochemical Atlas Series. (Keyworth, Nottingham: British Geological Survey) ISBN 0852721986. BGS (BRITISH GEOLOGICAL SURVEY), 1993. Southern Scotland and part of Northern England. Regional Geochemical Atlas Series. (Keyworth, Nottingham: British Geological Survey) ISBN $085272229 \mathrm{X}$.

BRE (Building Research Establishment), 1999. Radon: guidance on protective measures for new dwellings in Scotland. BR-376. 23 pp. ISBN 1860813348. 
BRITISH GEOLOGICAL SURVEY. 2007. Bedrock geology UK north 1:625 000 (north of National Grid Line 460 km N). 1:625 000. 5th ed. (Keyworth, Nottingham: British Geological Survey).

DARBY, S., HILL, D., AUVINEN, A., BARROS-DIOS, J.M., BAYSSON, H., BOCHICCHIO, F., DEO, H., FALK, R., FORASTIERE, F., HAKAMA, M., HEID, I., KREINENBROCK, L., KREUZER, M., LAGARDE, F., MÄKELÄINEN, I., MURIHEAD, C., OBERAIGNER, W., PERSHAGEN, G., RUANAORAVINA, A., RUOSTEENOJA, E., SCHAFFRATH ROSARIO, A., TIRMARCHE, M., TOMÁSEK, L., WJITLEY, E., WICHMANN, H-E and DOLL, R., 2005. Radon in homes and risk of lung cancer: collaborative analysis of individual data from 13 European case-control studies. British Medical Journal, Jan 2005; 330 (7485): 223-227. Epub 2004 Dec 21.

GREEN, B.M.R., MILES, J.C.H., and REES, D.M., 2009. Radon in Dwellings in Scotland: 2008 Review and Atlas. Health Protection Agency Radiation Protection Division, HPA-RPD-051. ISBN 978-0-85951-634-1. Chilton, UK.

HASLAM, H. W., 1975. Geochemical survey of stream waters and stream sediments from the Cheviot area. Rep. Inst. Geol. Sci. 75/6.

INSTITUTE OF GEOLOGICAL SCIENCES, 1978. Orkney. Regional Geochemical Atlas Series. (Keyworth, Nottingham: British Geological Survey) ISBN 0852720602.

INSTITUTE OF GEOLOGICAL SCIENCES, 1979. South Orkney and Caithness. Regional Geochemical Atlas Series. (Keyworth, Nottingham: British Geological Survey) ISBN 085272 0645.

JOHNSON, C.C, BREWARD, N., ANDER E.L. and AULT, L., 2005. G-BASE: baseline geochemical mapping of Great Britain and Northern Ireland. Geochemistry: Exploration, Environment, Analysis. 5, 347-357. 
MICHIE, U, McL., 1972. Further evidence of uranium mineralisation in Orkney. Trans. Inst. Min. Metall., 81, pp B53-54.

MILES, J.C.H.,1998. Mapping radon prone areas by lognormal modelling of house radon data. Health Physics, 74, 370378.

MILES, J.C.H., 2001. Temporal variation of radon levels in houses and implications for radon measurement strategies. Radiation Protection Dosimetry, 93, 369-376.

MILES, J.C.H, and APPLETON J.D., 2005. Mapping variation in radon potential both between and within geological units. Journal of Radiological Protection 25, 257-276. MILES J.C.H, APPLETON J.D, REES D.M, GREEN B.M.R, ADLAM K.A.M and MYERS, A.H., 2007. Indicative Atlas of Radon in England and Wales. ISBN: 978-0-85951-6082. 29 pp. Chilton, UK.

NRPB (NATIONAL RADIOLOGICAL PROTECTION BOARD), 1990. Limitation of Human Exposure to Radon in Homes. Documents of the NRPB: Volume 1, No. 1. ISBN 089591-322-X. Chilton, UK. NRPB (NATIONAL RADIOLOGICAL PROTECTION BOARD), 1991. Radon in Dwellings in Scotland. NRPB-M324. 31 pp. Chilton, UK.

NRPB (NATIONAL RADIOLOGICAL PROTECTION BOARD), 1993. Radon Affected Areas: Scotland. Documents of the NRPB, Volume 4, No. 6, 1993. 15 pp. Chilton, UK. NRPB (NATIONAL RADIOLOGICAL PROTECTION BOARD), 2000. Health Risks from Radon. UK: National Radiological Protection Board, Chilton, UK. Information booklet. NRPB (NATIONAL RADIOLOGICAL PROTECTION BOARD), 2003. Environmental Radon Newsletter. Issue 36, 2003. 
PLANT, J.A, BROWN, G.C, SIMPSON, P.R., and SMITH, R.T., 1980. Signatures of metalliferous granites in the Scottish Caledonides. Transactions of the Institute of Mining and Metallurgy, Section B, 89, B198 209.

SCOTTISH HOUSEHOLD SURVEY (SHS), SCOTTISH GOVERNMENT, 2008. Annual Report- Results from 2007. Published August 2008.

SIMPSON, P.R, PLANT, J. and COPE, M.J.B., 1976. Uranium abundance and distribution in some granites from northern Scotland and south west England as indicators of uranium provinces. In: JONES, M.J. (ed.), Geology, Mining and Extractive Processing of Uranium, (London: Institution of Mining and Metallurgy.) pp126-139. STONE, P., 2008. Bedrock Geology UK North. An explanation of the bedrock geology map of Scotland, northern England, Isle of Man and Northern Ireland- 1:625 000 fifth edition. (Keyworth, Nottingham: British Geological Survey) 88 pp.

STONE, P., BREWARD, N., MERRIMAN, R.J and PLANT, J.A., 2004. Regional geochemistry of cryptic geology: variations in trace element distribution across the Southern Uplands terrane, Scotland. Applied Earth Science (Trans. Inst. Min. Metall. B) $113,43-57$.

WATSON, S.J., Jones, A.L., Oatway, W.B., and Hughes, J.S. 2005. HPA-RPD-001 Ionising Radiation Exposure of the UK Population: 2005 Review. ISBN 0-85951-558-3. Chilton, UK.

WEBB, P.C. and BROWN, G.C., 1984. The Eastern Highlands granites: heat production and related geochemistry. Report in series: Investigation of the geothermal potential of the UK. British Geological Survey. 